DEPARTMENT OF THE INTERIOR

U. S. GEOLOGICAL SURVEY

\title{
A selected bibliography of sand and gravel resources \\ Arctic Coastal Plain, Alaska
}

by

John P. Galloway ${ }^{1}$ and L. David Carter ${ }^{2}$

Open-File Report 97-702

This report (map) is preliminary and has not been reviewed for conformity with U.S. Geological Survey editorial standards and stratigraphic nomenclature. Any use of trade names used in this report is for descriptive purposes only and does not imply endorsement by the United States Geological Survey.

${ }^{1}$ U.S. Geological Survey, 345 Middlefield Road, Menlo Park, California 94025-3591

2 U.S. Geological Survey, 4200 University Drive, Anchorage, Alaska 99508-4667 


\section{INTRODUCTION}

Given the demand for geologic information and an increasing interest, both at the national and international levels, in geological processes in arctic environments, the development of a selected bibliography of sand and gravel resources of the Arctic Coastal Plain, Alaska, was prepared to help land use managers, at both the federal and state level, to prepared reports involving the use of sand and gravel resources located in the lands they manage.

References for the bibliography were copied from a variety of sources (see below). Although completeness is desired, this bibliography has not benefited from a thorough search of all doctoral and master's theses and unpublished literature held by private industry.

Any errors or omissions in this report are those of the authors. The authors would appreciate any comments on the bibliography, especially additions or errors in the citations.

\section{SOURCES OF BIBLIOGRAPHIC DATA}

References were copied from the following compilations. References were not checked for accuracy (except in cases of obvious errors). All references are in standard U.S. Geological Survey bibliographic format.

Bartsch-Winkler, Susan, 1977, Geologic mapping in Alaska; U.S. Geological Survey, post-1930, scales 1:96,000 to 1:250,000: U.S. Geological Survey Open-File Report 77-681, 1 sheet.

Bartsch-Winkler, Susan, 1977, Geologic mapping in Alaska; U.S. Geological Survey, post-1930, scales 1:20,000 to 1:63,360: U.S. Geological Survey Open-File Report 77-682, 1 sheet.

Carter, L.D., 1983, Engineering-geologic maps of northern Alaska: Teshekpuk quadrangle: U.S. Geological Survey Open-File Report 83-634, scale 1:250,000, 2 sheets.

Carter, L.D., Ferrians, O.J., Jr., and Galloway, J.P., 1986, Engineering-geologic maps of northern Alaska, coastal plain and foothills of the Arctic National Wildlife Refuge: U.S. Geological Survey Open-File Report 86334,10 p., scale $1: 250,000,2$ sheets.

Carter, L.D., and Galloway, J.P., 1985, Engineering-geologic maps of northern Alaska, Harrison Bay quadrangle: U.S. Geological Survey Open-File Report 85-256, 48 p., scale 1:250,000, 2 sheets.

Carter, L.D., and Galloway, J.P., 1986, Engineering-geologic maps of northern Alaska, Umiat quadrangle: U.S. Geological Survey Open-File Report 86-335, 17 p., scale 1:250,000, 2 sheets.

Carter, L.D., and Galloway, J.P., 1988, Engineering-geologic maps of northern Alaska, Ikpikpuk River quadrangle: U.S. Geological Survey Open-File Report 88-375, 19 p., scale 1:250,000, 2 sheets.

Ferrians, O.J., Jr., 1990 [unpublished] Bibliography of Alaskan engineering-geologic maps published by the U.S. Geological Survey, October 1990, Anchorage, AK 99508

Gallloway, John P., 1988, A bibliography of selected geologic and engineering-geologic literature of northern Alaska (Arctic Coastal Plain and Northern Foothills): U.S. Geological Survey Open-File Report 88-395, $34 \mathrm{p}$.

GeoRef CD-Rom disk. (Bibliography and Index of Geology, 1785 through December 1996)

Hamilton, T.D., and Bauer, D.P., 1984, Engineering-geologic maps of northern Alaska: Howard Pass quadrangle: U.S. Geological Survey Open-File Report 84-401, scale 1:250,000.

Hopkins, B.A., compiler, 1983, Geologic maps on Alaska published by the U.S. Geological Survey, post1930: scales 1:20,000 and 1:63,360 (through October 1982): U.S. Geological Survey Open-File Report 83-578, 17 p., 1 sheet.

Hopkins, B.A., compiler, 1983, Geologic maps on Alaska published by the U.S. Geological Survey, post1930: scales 1:96,000 to 1:250,000 (through October 1982): U.S. Geological Survey Open-File Report 83-577, 19 p., 1 sheet.

Morrone, J.F., compiler, 1982, Preliminary bibliography of Alaskan geologic maps by 1:250,000 quadrangle: U.S. Geological Survey Open-File Report 82-195, 64 p.

Pinney, D.S., 1991, Index of surficial geologic maps in Alaska: Alaska Division of Geological and Geophysical Surveys Public-Data File 91-25, 48 p., 1 sheet, scale 1:2,500,000.

Polar Pac CD-RO, 1996, Issue 4, WLN, P.O. Box 3888, Lacey, WA 98509-3888.

State of Alaska, Department of Natural Resources, 1993, Publication catalog of the Division of Geological and Geophysical Surveys Information Circular 11, $127 \mathrm{p}$. 
U.S. Geological Survey, Geoindex on CD-Rom disk, through December 1996.

Williams, J.R., 1983, Engineering-geologic maps of northern Alaska, Meade River quadrangle: U.S. Geological Survey Open-File Report 83-294, 29 p., scale 1:250,000.

Williams, J.R., 1983, Engineering-geologic maps of northern Alaska, Wainwright quadrangle: U.S. Geological Survey Open-File Report 83-457, 28 p., scale 1:250,000.

Williams, J. R., and Carter, L.D., 1984, Engineering-geologic maps of northern Alaska: Barrow quadrangle: U.S. Geological Survey Open-File Report 84-124, 39 p., scale 1:250,000, 2 sheets.

Yeend, Warren, 1983, Engineering-geologic maps of northern Alaska, Lookout Ridge quadrangle: U.S. Geological Survey Open-File Report 83-279, scale 1:250,000, 2 sheets.

Yeend, Warren, 1984, Engineering-geologic maps of northern Alaska: Utukok River quadrangle: U.S. Geological Survey Open-File Report 84-682, scale 1:250,000, 2 sheets.

\section{REFERENCES}

Adam, K.M., 1978a, Building and operating winter roads in Canada and Alaska: Environmental Studies No. 4, Department of Indian and Northern Affairs, Ottawa, Canada, 22 p.

Adam, K.M., 1978b, Winter road construction techniques, in Proceedings, Conference on Applied Techniques for Cold Environments, Anchorage, Alaska, ASCE, p. 429-440.

Alaska Business News Letter, 1980, Arctic Gravel Extraction Study Results and Mining Manual Released: Alaska Business News Letter, v.7, p. 2, (Nov. 14).

Alaska Construction and Oil, 1981, Gravel Pad Construction - Prudhoe Bay: Alaska Construction and Oil, v. 22, p. 50, (Oct.).

Alaska Construction and Oil, 1981,Gravel Pad Expansion - North Slope Borough: Alaska Construction and Oil, v. 22, p. 44 , (Nov.).

Alaska Construction and Oil. 1981, Gravel Pad Construction - Deadhorse: Alaska Construction and Oil, v.22, p. 50, (Oct.).

Alaska Department of Fish and Game, 1993, North Slope gravel pit performance standards, Alaska Department of Fish and Game, Habitat and Restoration Division, United States Office of Ocean and Coastal Resource Management, 1 v. (various pagings).

Alaska Department of Highways, 1971, Proposed highway : Yukon River to Arctic Ocean: environmental impact statement, photo supplement 10 leaves.

Alaska from the Inside, 1984, Huge North Slope gravel pit planned: Alaska from the Inside, no. 45, p. 2 (Nov. 7).

Alaska from the Inside, 1986, Gravel on demand: Alaska from the Inside, no. 46, p. 3, 2 col., (Nov. 12).

Alaska Industry, 1980, Arctic Gravel Study, Mining Manual Is Out: Alaska Industry, v. 12, p. 29, (Dec.).

Arctic Institute of North America, 1974, The Alaskan arctic coast, a background study of available knowledge: prepared for Department of the Army, Corps of Engineers, Alaska District, contract DACW-85-74-C$0020,551 \mathrm{p}$.

Baker, Michael, Jr., 1970, Haul road construction, Yukon River to Prudhoe Bay, Alaska: drainage report: Michael Baker, Jr., Inc., Trans Alaskan Pipeline System, 1 v., no. MB-5 (various pagings, some folded).

Barnes, P.W., Reimnitz, E., and Ross, C.R., 1980, Neashore surficial sediment textures - Beaufort Sea, Alaska: Environmental assessment of the Alaskan continental shelf: Boulder, Colo., National Oceanic and Atmospheric Administration, OCEAP Quartery Report 2, p. 132-170.

Barnes, Peter and Reiss, Thomas, 1982, Erosion and migration of an artificial sand and gravel island, Niakuk III, Beaufort Sea, Alaska: U.S. Geological Survey Open File Report 82-608, 10 p.

Bennett, L.F., 1986, Winter highway construction: Alaska Department of Transportation and Public Facilities Report AK-RD-87-29, 33 p.

Berg, R.L., Brown, J. and Haugen, R.K., 1978, Thaw penetration and permafrost conditions associated with the Livengood to Prudhoe Bay road, Alaska: International Conference on Permafrost 3rd, Edmonton, Alberta, Canada, p. 615-621.

Black, R.F., 1951, Eolian deposits of Alaska: Arctic, v. 4, no. 2, p. 89-111.

Black, R.F., 1957, Gubik Formation of Quaternary age in northern Alaska [abs.]: Geological Society of America Bulletin, v. 68, p. 1701.

Black, R.F., 1957, Some problems in engineering geology caused by permafrost in the Arctic Coastal Plain, northern Alaska: Arctic, v. 10, no. 4, p. 230-240. 
Black, R.F., 1964, Gubik Formation of Quaternary age in northern Alaska: U.S. Geological Survey Professional Paper 302-C, p. 59-91.

Brazo, G.M., 1984, Material site investigations, Deadhorse parallel taxiway: Alaska Department of Transportation and Public Facilities, Northern Region Design and Construction, Engineering geology and soils report, 13 p.

Brewer, M.C., 1984, Petroleum exploration and protection of the environment on the National Petroleum Reserve in Alaska, in International Conference on Permafrost, 4th, Fairbanks, Alaska, 1983, Final Proceedings: Washington, D.C., National Academy Press, p. 133-134.

Briggs, S.R., 1983, Geology report for proposed Beaufort Sea OCS sand and gravel lease sale: U.S. Geological Survey Open File Report 83-606, 65 p.

Briggs, S.R., Tuimil, L.J., and Dunton, K.H., 1985, Environmental effect of gravel island construction OCS-Y0191 (BF-37) Beechey Point, Block 480, Stefansson Sound, Alaska : 1984 supplemental study, Harding Lawson Associates, Exxon Company U.S.A., v. 57 leaves

Britton, M.E., 1957, Vegetation of the arctic tundra, in Arctic Biology, Annual Biology Colloquium, 18th, Corvallis, Oregon State University, p. 26-61.

Brosgé, W.P., Dutro, J.T., Jr., Mangus, M.D., and Reiser, H.N., 1960, Geologic map of the eastern Brooks Range, Alaska: U.S. Geological Survey Open-File Report 60-20, scale 1:250,000, 7 sheets.

Brosgé, W.P., and Reiser, H.N., 1976, Preliminary geologic and mineral resources maps (excluding petroleum), Arctic National Wildlife Range, Alaska: U.S. Geological Survey Open-File Report 76-539, 4 p., 4 maps, scale 1:500,000.

Brosgé, W.P., and Whittington, C.L., 1966, Geology of the Umiat-Maybe Creek region, Alaska: U.S. Geological Survey Professional Paper 303-H, p. 501-638.

Brown, J., Brockett, B.E., and Howe, K.E., 1984, Interaction of gravel fill, surface drainage and culverts with permafrost terrain: Alaska Department of Transportation and Public Facilities, Report AK-RD-84-11.

Bulletin, Biological Services Program News, 1978, Gravel removal can alter wildlife habitat: Bulletin, Biological Services Program News v. 2, p. 8, (Spring).

Burns, C.D., 1978, Traffic tests for expedient airfield construction concepts for possible application in the National Petroleum Reserve Alaska (NPRA): USAE Waterways Experimental Station Technical Report GL-79-2, $53 \mathrm{p}$.

Cabot, E.C., 1947, The northern Alaskan coastal plain interpreted from aerial photographs: Geographical Review, v. 37, no. 4, p. 639-648.

Cannon, P.J., 1983, Floodplain mapping of rivers along the Chukchi Sea/Arctic Ocean coastal plain, Alaska: North Slope Borough, Coastal Management Program, NSB floodplain studies report ; no. 2, 35 p.

Carlson, P.R., Roy, C.J., Hussey, K.M., Davidson, D.T., and Handy, R.L., 1959, Geology and mechanical stabilization of Cenozoic sediments near Point Barrow, in Davidson, D.T., and others, The geology and engineering characteristics of some Alaskan soils: Ames, Iowa State University, Engineering Experiment Station Bulletin 186, p. 101-128.

Carter, L.D., 1981, A Pleistocene sand sea on the Alaskan Arctic Coastal Plain: Science, v. 211, no. 4480, p. 381383.

Carter, L.D., 1982, Late Wisconsin desertification in northern Alaska [abs.]: Geological Society of America, Abstracts with Programs, v. 14, no. 7, p. 461.

Carter, L.D., 1983, Engineering-geologic maps of northern Alaska: Teshekpuk quadrangle: U.S. Geological Survey Open-File Report 83-634, scale 1:250,000.

Carter, L.D., 1983, Fossil sand wedges on the Alaskan arctic coastal plain and their paleoenvironmental significance, in International Conference on Permafrost, 4th, Fairbanks, Alaska, 1983, Proceedings: Washington, D.C., National Academy Press, p. 109-114.

Carter, L.D., 1983, A Pleistocene sand desert in arctic Alaska [abs.], in U.S. Geological Survey Polar Research Symposium, abstracts with program: U.S. Geological Survey Circular 911, p. 36.

Carter, L.D., 1983, Cenozoic glacial and glaciomarine deposits of the central North Slope, Alaska, in Thorson, R.M., and Hamilton, T.D., eds., Glaciation in Alaska, extended abstracts from a workshop: Fairbanks, University of Alaska Museum Occasional Paper No. 2, p. 17-21. 
Carter, L.D., and Brigham-Grette, J.K., and Hopkins, D.M., 1986, Late Cenozoic marine transgressions of the Alaskan Arctic Coastal Plain, in, Heginbottom, J. A., and Vincent, J. S., eds., Correlation of Quaternary deposits and events in the area around the Beaufort Sea, abstracts of the Joint Canadian-American Workshop: Geological Survey of Canada Open-File Report 1237, p. 21-26.

Carter, L.D., Ferrians, O.J., Jr., and Galloway, J.P., 1986, Engineering-geologic maps of northern Alaska, coastal plain and foothills of the Arctic National Wildlife Refuge: U.S. Geological Survey Open-File Report 86334,10 p., scale $1: 250,000,2$ sheets.

Carter, L.D., and Galloway, J.P., 1979, Arctic Coastal Plain pingos in National Petroleum Reserve in Alaska, in Johnson, K.M. and Williams, J.R., eds., The United States Geological Survey in Alaska Accomplishments during 1978: U.S. Geological Survey Circular 804-B, B33-B35.

Carter, L.D., and Galloway, J.P., 1979, Southward-progressing stabilization of Holocene eolian sand on the western Arctic Coastal Plain, in Johnson, K.M. and Williams, J.R., eds., The United States Geological Survey in Alaska - Accomplishments during 1978: U.S. Geological Survey Circular 804-B, B37-B39.

Carter, L.D., and Galloway, J.P., 1982, Terraces of the Colville River delta region, Alaska, in Coonrad, W.L., ed., The United States Geological Survey in Alaska - Accomplishments during 1980: U.S. Geological Survey Circular 884, p. 49-51.

Carter, L.D., and Galloway, J.P., 1985, Engineering-geologic maps of northern Alaska, Harrison Bay quadrangle: U.S. Geological Survey Open-File Report 85-256, 48 p., scale 1:250,000, 2 sheets.

Carter, L.D., and Galloway, J.P., 1986, Engineering-geologic maps of northern Alaska, Umiat quadrangle: U.S. Geological Survey Open-File Report 86-335, 17 p., scale 1:250,000, 2 sheets.

Carter, L.D., and Galloway, J.P., 1988, Engineering-geologic maps of northern Alaska, Ikpikpuk River quadrangle: U.S. Geological Survey Open-File Report 88-375, 19 p., scale 1:250,000, 2 sheets.

Carter, L.D., and Robinson, S.W., 1978, Eolian sand and interbedded organic horizons at Keolok Creek on the Arctic Coastal Plain of Alaska, possible regional implications: U.S. Geological Survey Open-File Report 78-320, $26 \mathrm{p}$.

Carter, L.D., and Robinson, S.W., 1981, Minimum age of beach deposits north of Teshekpuk Lake, Arctic Coastal Plain, in Albert, N.R.D., and Hudson, Travis, eds., The United State Geological Survey in Alaska Accomplishments during 1979: U.S. Geological Survey Circular 823-B, p. B8-B9.

Chapman, R.M., Detterman, R.L., and Mangus, M.D., 1964, Geology of the Killik-Etivluk rivers region, Alaska: U.S. Geological Survey Professional Paper 303-F, p. 325-407.

Chapman, R.M., and Sable, E.G., 1960, Geology of the Utukok-Corwin region, northwestern Alaska: U.S. Geological Survey Professional Paper 303-C, p. 47-167.

Condo, A.C., McGrogan, J.F., and Burt, G.R., 1971, Insulated gravel embankments for arctic road construction: Society of Petroleum Engineers of AIME 4, $6 \mathrm{p}$.

Craig, J.D., and Thrasher, G.P., 1982, Environmental geology of Harrison Bay, northern Alaska: U.S. Geological Survey Open-File Report 82-35, 25 p., 6 pls.

Crory, F.E., Berg, R.L., Burns, C.D., and Kachadoorian, Reuben, 1979, Design considerations for airfields in NPRA, in American Society of Civil Engineers, Conference on applied techniques for cold environments, Anchorage, Alaska, 1978, Proceedings, p. 441-458.

Crory, F.E., 1991, Construction guidelines for oil and gas exploration in northern Alaska: U.S. Army Cold Regions Research and Engineering Laboratory Report 91-21, 83 p.

Detterman, R.L., Bickel, R.S., and Gryc, George, 1963, Geology of the Chandler River region Alaska: U.S. Geological Survey Professional Paper 303-E, p. 223-324.

Duguid, J.O., 1971, Thin gravel deposits on wave-eroded cliffs near Barrow, Alaska: Arctic, v. 24, no. 4, p. 304306.

Emmel, K.S., 1982, Geologic literature on the North Slope of Alaska, 1974-1980: Alaska Division of Geologic and Geophysical Surveys Special Report 29, 127 p.

Esch, D.C., 1984, Design and performance of road and railway embankments on permafrost, in International Conference on Permafrost, 4th, Fairbanks, Alaska, 1983, Final Proceedings: Washington, D.C., National Academy Press, p. 25-30.

Esche, D.C., 1983, Evaluation of experimental design features for roadway construction over permafrost: Proceedings Permafrost, 4th International Conference, Washington, DC, National Academy Press, p. 283288. 
Ferrians, O.J., Jr., compiler, 1965, Permafrost map of Alaska: U.S. Geological Survey Miscellaneous Investigations Series Map I-445, scale 1:2,500,000.

Ferrians, O.J., Jr., and Kachadoorian, R., and Green, G.W., 1969, Permafrost and related engineering problems in Alaska: U.S. Geological Survey Professional Paper 678, 37 p.

Galloway, J.P., 1982, Grain-size analyses of 20 eolian sand samples from northern Alaska, in Coonrad, W., ed., The United State Geological Survey in Alaska - Accomplishments during 1980: U.S. Geological Survey Circular 884, p. 51-53.

Galloway, J.P., and Carter, L.D., 1978, Preliminary map of pingos in National Petroleum Reserve in Alaska: U.S. Geological Survey Open-File Report 78-795, scale 1:500,000.

Galloway, J.P. and Carter, L.D., 1993, Late Holocene longitudinal and parabolic dunes in northern Alaska: Preliminary interpretations of age and paleoclimatic significance, in Dusel-Bacon, Cynthia and Till, A.B. eds., Geologic studies in Alaska by the U.S. Geological Survey during 1992: U.S. Geological Survey Bulletin 2068, p. 3-11.

Galloway, J.P. and Carter, L.D., 1994, Paleowind direction for Late Holocene dunes on the western Arctic coastal plain, northern Alaska, in Till, A.B. and Moore, T.M. eds., Geologic studies in Alaska by the U.S. Geological Survey during 1993: U.S. Geological Survey Bulletin 2107, p. 27-30.

Goodman, M.A., 1978, Permafrost problems for gravel islands and permafrost data collection -- Beaufort Sea well completions [microform]: Arctic Petroleum Operators Association, Pallister Resource Management Ltd., APOA Report 152-1.

Gropp, D.L., 1977, 1976/1977 geophysical survey of rivers of the Alaskan Arctic coastal plain between Prudhoe Bay and the Canadian border: Anchorage, Alaska Arctic Gas Study Company, 1977, 83 p.

Grybeck, Donald, Beikman, H.M., Brosgé, W.P., Tailleur, I.L., and Mull, C.G., 1977, Geologic map of the Brooks Range, Alaska: U.S. Geological Survey Open-File Report 77-166B, scale 1:1,000,000, 2 sheets.

Hamilton, T.D., 1979, Surficial geology, Chandler Lake quadrangle, Alaska: U.S. Geological Survey Miscellaneous Field Studies Map MF 1121, scale 1:250,000.

Hamilton, T.D., and Bauer, D.P., 1984, Engineering-geologic maps of northern Alaska: Howard Pass quadrangle: U.S. Geological Survey Open-File Report 84-401, scale 1:250,000.

Hardin, Deborah, Barnes, Peter, and Reimnitze, Erk, 1977, Distribution and character of naleds in northeastern Alaska: U.S. Geological Survey Open-File Report 77-91, 28 p.

Hartman, D.C., 1973, Geology and mineral evaluation of the Arctic Wildlife Range, northeast Alaska: Alaska Division of Geological and Geophysical Surveys Open-File Report AOF-22, 14 p.

Hartz, R.W., 1978, Erosional hazards map of the arctic coast of the National Petroleum Reserve, Alaska: U.S. Geological Survey Open-File Report 79-406, 7 p., approx. scale 1:817,300.

Hartz, R.W., 1978, High spindrift and storm surge limits, Icy Cape to the Colville River, in Hopkins, D.M., and Hartz, R.W., Shoreline history of Chukchi and Beaufort Seas as an aid to predicting offshore permafrost conditions: U.S. Department of Commerce, NOAA, OCSEAP, Environmental Assessment of the Alaskan Continental Shelf: Annual Report, Appendix IV, 1 p., 4 maps.

Hemming, C.R., 1988, Aquatic habitat evaluation of flooded North Slope gravel mine sites (1986-1987): Alaska Department of Fish and Game, Division of Habitat, Technical report no. 88-1, 69 p.

Hemming, C.R., 1990, Fisheries investigations of flooded North Slope gravel mine sites, 1989: Alaska Department of Fish and Game, Division of Habitat, Technical report 90-2, 38 p.

Hemming, C.R., 1992, Fish and habitat investigations of flooded North Slope gravel mine sites, 1990: Alaska Department of Fish and Game, Habitat Division, Technical report no. 91-3, 44 p.

Hemming, C.R., Scannell, P.K., and Winters, J.F., 1989, Limnological and fisheries investigations of flooded North Slope gravel mine sites, 1988: Alaska Department of Fish and Game, Habitat Division, Technical report no. 89-1, 60 p.

Hendershot, J.R., 1969, Report to files on Trans Alaska Pipeline System Livengood to Yukon haul road : summer construction methods: Trans Alaska Pipeline System, 40 p.

Hopkins, D.M., and Hartz, R.M., 1978, Coastal morphology, coastal erosion, and barrier island of the Beaufort Sea, Alaska: U.S. Geological Survey Open-File Report 78-1063, 54 p.

Hume, J.D., 1964, Shoreline changes near Barrow, Alaska, caused by the storm of October 3, 1963, in Science in Alaska, Alaskan Science Conference, 15th, College, Alaska, Proceedings: p. 96.

Hume, J.D., 1965, Sea level changes during the last 2,000 years at Point Barrow, Alaska: Science, v. 150, no. 3700 , p. $1165-1166$. 
Hume, J.D., and Schalk, Marshall, 1963, The effects of beach borrowing in the Arctic [abs.]: Eos [American Geophysical Union Transactions], v. 44, no. 1, p. 67.

Hume, J.D., and Schalk, Marshall, 1964, The effects of ice push on arctic beaches: American Journal of Science, v. 262 , no. 2, p. 267-273.

Hume, J.D., and Schalk, Marshall, 1964, The effects of beach borrow in the Arctic: Shore and Beach, April issue.

Hume, J.D., and Schalk, Marshall, 1967, Shoreline processes near Barrow, Alaska, a comparison of the normal and the catastrophic: Arctic, v. 20, no. 2, p. 86-103.

Hume, J.D., Schalk, Marshall, and Hume, H.W., 1972, Short-term climate changes and coastal erosion, Barrow, Alaska: Arctic, v. 25, no. 4, p. 272-278.

Johnson, L.A.,1987, Management of northern gravel sites for successful reclamtion: A review: Arctic and Alpine Research, v. 19 no. 4, p. 530-536.

Joyce, M.R., Rundquist, L.A., and Moulton, L.L., 1980, Gravel removal guidelines manual for arctic and subarctic floodplains: U.S. Department of the Interior, U.S. Fish and Wildlife Service, Water Resource Analysis Project, Office of Biological Services, $169 \mathrm{p}$.

Kachadoorian, Reuben, Crory, F.E., and Berg, R.L., 1978, Studies of proposed airfields at Inigok and Tunalik well sites, NPRA, in Johnson, K.M., ed., The United States Geological Survey in Alaska - Accomplishments during 1977: U.S. Geological Survey Circular 772-B, p. B22-B24.

Kachadoorian, Reuben, Crory, F.E., and Berg, R.L., 1979, Design of airfields in National Petroleum Reserve in Alaska, in Johnson, K.M. and Williams, J.R., eds., The United State Geological Survey in Alaska Accomplishments during 1978: U.S. Geological Survey Circular 804-B, p. B51-B52.

Kachadoorian, Reuben, 1984, Engineering geology studies in the National Petroleum Reserve, Alaska: U.S. Geological Survey, Open-File Report 83-6, 37 leaves.

Keller, A.S., Morris, R.H., and Detterman, R.L., 1961, Geology of the Shaviovik and Sagavanirktok Rivers region, Alaska: U.S. Geological Survey Professional Paper 303-D, p. 169-222.

Klinger, L.F., Walker, D.A., and Webber, P.J., 1983, The effects of gravel roads on Alaskan Arctic Coastal Plain tundra: Proceedings Permafrost, 4th International Conference, Washington, DC, National Academy Press, p. 628-633.

Koehmstedt, P.L., 1986, Sand stabilization for remote airfields [microform] : final report: Alaska Department of Transportation and Public Facilities, Division of Planning, Research Section, Report no. AK-RD-86-22, $45 \mathrm{p}$.

LaBelle, J.C., 1973, Fill materials and aggregate near Barrow, Naval Petroleum Reserve No. 4, Alaska: Arctic Institute of North America, Contract NOd-9915 (72-2), Office of Naval Petroleum and Oil Shale Reserves, $147 \mathrm{p}$.

LaBelle, J.C., 1976, Fill materials between Barrow and Colville River, northern Alaska: University of Alaska, Institute of Marine Science, Occasional Publication 4, p. 161-172.

Lang, James D., 1956, Construction and maintenance of airfields in the far north regions: J.D. Lang, Technical Assistant to Chief of Naval Operations for Polar Projects (OP-03A3), 9 p.

Lathram, E.H., 1965, Preliminary geologic map of northern Alaska: U.S. Geological Survey Open-File Report 6596, scale $1: 1,000,000,2$ sheets.

LaVielle, C.C., Gladden, S.C., and Zeman, A.R., 1983, Nuiqsut airport dredge project: Proceedings Permafrost, 4th International Conference, Washington, DC, National Academy Press, p. 689-694.

Leffingwell, E. de K, 1919, The Canning River region, northern Alaska: U.S. Geological Survey Professional Paper 109, $251 \mathrm{p}$.

Lewellen, R.I., 1972, Studies on the fluvial environment, Arctic Coastal Plain Province, northern Alaska: Littleton, Colo., 2 v., 282 p., (Published privately).

Lewellen, R.I., 1973, The occurrence and characteristics of nearshore permafrost, northern Alaska, in International Conference on Permafrost, North American Contribution, 2nd, Yakutsk, U.S.S.R.: Washington, D.C., National Academy of Sciences, p. 131-136.

Lewellen, R.I., 1974, Offshore permafrost of the Beaufort Sea, Alaska, in Reed, J.C., and Sater, J.E., eds., The coast and shelf of the Beaufort Sea: proceedings of a symposium on Beaufort Sea Coast and shelf Research: Arctic Institute of North America, p. 417-426.

Lewellen, R.I., 1977, A study of Beaufort Sea coastal erosion, northern Alaska, in U.S. Department of Commerce, NOAA, OCSEAP, Environmental Assessment of the Alaskan Continental Shelf: Final Reports of Principal Investigators, v. 15, p. 491-527. 
Lewis, C.R., 1959, Geology of Barter Island and the Alaska arctic coast, p. 61-83, in U.S. Geological Survey, Military Geology Branch, preliminary report of the Mt. Chamberlin-Barter Island project, Alaska, 1958: Progress report for Air Force Cambridge Research Center, Bedford, Mass., 83 p.

Lewis, C.R., 1962, Icing mounds on Sadlerochit River, Alaska: Arctic, v. 15, no. 2, p. 145-150.

Lindsay, J.E., 1992, Three-dimensional geologic block model of a polar fan-delta complex, Canning River, North Slope, in Hamilton, D.E. and Jones, D.A., eds., Computer modeling of geologic surfaces and volumes, AAPG Computer Applications in Geology 1, p. 183-200, Tulsa, OK, American Association of Petroleum Geologists.

Lotspeich, F.B., 1971, Environmental guidelines for road construction in Alaska: Environmental Protection Agency, Alaska Water Laboratory Report no. 1610GOI 08/71, College, Alaska, 127 p.

Luscher, Ulrich and Afifi, S.S., 1973, Thaw consolidation of Alaskan silts and granular soils, in Permafrost; North American Contribution, Second International Conference, Physics, Physical Chemistry and Mechanics of Frozen Ground and Ice: National Academy of Science, Washington DC., p. 325-334.

MacCarthy, G.R., 1953, Recent changes in the shoreline near Point Barrow, Alaska: Arctic, v. 6, no. 1, p. 44-51.

MacCarthy, G.R., 1958, Glacial boulders on the arctic coast of Alaska: Arctic, v. 11, no. 2, p. 71-85.

MacKay, J.R., 1971, The origin of massive icy beds in permafrost, western arctic coast, Canada: Canadian Journal of Earth Sciences, v. 8, no. 4, p. 397-422.

Maniilaq Association, 1984, NANA region gravel study : site identification and policies: NANA Regional Corporaton, Alaska. Department of Transportation and Public Facilities, 110 leaves.

Martinson, M.A. and Livingston, H.R., 1984, Barrow Airport, Barrow Airport material site: Alaska Department of Transportation and Public Facilities, Northern Region Design and Construction, $32 \mathrm{p}$.

McCulloch, D.S., 1967, Quaternary geology of the Alaskan shore of Chukchi Sea, in Hopkins, D.M., ed., The Bering Land Bridge: Stanford, Calif., Stanford University Press, p. 91-120.

McKendrick, J.D, Scorup, P.C., Fiscus, W.E., and Turner, Gwendo-Lyn, 1992, Gravel vegetation experiments Alaska North Slope: Agroborealis, v. 24, no. 1 (Jan.) p. 25+.

McKenzie, L.S., and Walker, H.J., 1974, Morphology of an arctic river bar: Baton Rouge, Louisiana State University, Coastal Studies Institute Technical Report.

McLean, R.F., 1993, North Slope gravel pit performance guidelines: Alaska Department of Fish and Game, Habitat and Restoration Division, Technical report 93-9 (various pagings).

Meehan, R, and Nickles, J.R., 1988, Oil development in northern Alaska: A guide to the effects of gravel placement on wetlands and waterbirds: Anchorage, Fish and Wildlife Service, Report PB-88224407/XAB, $211 \mathrm{p}$.

Meehan, R.H., 1988?, Oil development in Alaska : a guide to the effects of gravel placement on wetlands and waterbirds: Environmental Research Laboratory, Corvallis, Office of Research and Development, U.S. Environmental Protection Agency, 206 leaves in various foliations.

Metz, M.C., 1984, Pipeline workpads in Alaska, in International Conference on Permafrost, 4th, Fairbanks, Alaska, Final Proceedings: Washington, D.C., National Academy Press, p. 106-108.

Morrissey, L.A., and Ennis, R.A., 1981, Vegetation mapping of the National Petroleum Reserve in Alaska using LANDSAT digital data: U.S. Geological Survey Open-File Report 81-315, 25 p.

Mowatt, T.C., Naidu, A.S., and Veach, Nomok, 1974, Clay mineralogy of the lower Colville River and Colville delta, north arctic Alaska: Fairbanks, Alaska Division of Geological and Geophysical Surveys Open File Report AOF-45, $39 \mathrm{p}$.

Mowatt, T.C. and Naidu, A.S., 1982, Gravels from the Alaska continental shelf, Beaufort Sea, Arctic Ocean, petrological character and implications for sediment source and transport: Fairbanks, Alaska Division of Geology and Geophysics Open File Report 43, 70 p.

Naidu, A.S. and Mowatt, T.C., 1994, Origin of gravels from the southern coast and continental shelf of the Beaufort Sea, Arctic Alaska: International Conference on Arctic Margins, Anchorage, AK, Sept. 2-4, 1992, Proceedings, p. 351-356.

Nelson, G.L., 1977, North Slope water resources studies, in Blean, K.M., ed., The United States Geological Survey in Alaska - Accomplishments during 1976: U.S. Geological Survey Circular 751-B, p. B31.

North Slope Borough, 1973, Cooper Island borrow material feasibility study, Hewitt V. Lounsbury and Associates, North Slope Bourough (Alaska), 81 leaves.

O'Sullivan, J.B., 1961, Quaternary geology of the Arctic Coastal Plain, northern Alaska: Ames, Iowa State University of Science and Technology, Ph.D. thesis, $191 \mathrm{p}$. 
O'Sullivan, J.B., Davidson, D.T., Roy, C.J., Handy, R.L., and Hussey, K.M., 1959, Crude oil for stabilization of soil materials at Point Barrow, in Davidson, D.T., and others, The geology and engineering characteristics of some Alaskan soils: Ames, Iowa State University, Engineering Experiment Station Bulletin 186, p. 129-149.

O'Sullivan, J.B., and Hussey, K.M., 1957, Problems associated with soil stabilization in the vicinity of Point Barrow, Alaska: Ames, Iowa Academy of Sciences, Proceedings, v. 64, p. 429-442.

Paige, Sidney, Foran, W.T., and Gilluly, James, 1925, Reconnaissance of the Point Barrow region, Alaska: U.S. Geological Survey Bulletin 772, 32 p.

Payne, T.G., and others, 1951, Geology of the arctic slope of Alaska: U.S. Geological Survey Oil and Gas Investigations Map OM-126, scale 1:1,000,000, 3 sheets.

Peterson, K.M., and Billings, W.D., 1978, Geomorphic processes and vegetation change along the Meade River sand bluffs in northern Alaska: Arctic, v. 31, no. 1, p. 7-23.

Péwé, T.L., and Church, R.E., 1962, Age of the spit at Barrow, Alaska: Geological Society of America Bulletin, v. 73 , no. 10 , p. $1287-1292$.

Phukan, Arvind, 1985, Frozen Ground Engineering, Prentice-Hall, Inc. New Jersey, 336 p.

Pollard, R.H., Rodriques, Robert, and Wilkinson, R.C., 1990, Wildlife use of disturbed habitats in arctic Alaska : 1989 final report, LGL Alaska Research Associates,BP Exploration (Alaska) Inc., 1 v. (various pagings).

Rampton, V.N., 1982, Quaternary geology of the Yukon coastal plain: Geological Survey of Canada Bulletin 317, 49 p., with map.

Rawlinson, S.E., 1990, Surficial geology and morphology of the Alaskan central Arctic Coastal Plain: Fairbanks, Alaska Division of Geological and Geophysical Surveys, Public-data File 90-27, 311 p.

Reckard, M., 1989, Cost-effectiveness of geotextiles: Review of Performance in Alaska Roads, Final Report: Alaska, Alaska Department of Transportation and Pubic Facilities, Report FHWA-AK-RD-90-04, 55 p.

Reger, R.D., and Combellick, R.A., 1991, Directory of aggregate, rock, and soil producers in Alaska: Alaska, Division of Geological and Geophysical Surveys, 1990, Information Circular 32, 55 p.

Reimers, Stephen, 1980, Drilling and sampling in frozen ground; a few basics, a few problems: The Northern Engineer, v.12, no. 2, p. 13-17.

Reimnitz, Erik, Barnes, P.W., Rearic, D.M., Minkler, P.W., Kempema, E.W., and Reiss, T.E., 1982, Marine geologic investigations in the Beaufort Sea 1981 and preliminary interpretations for regions from the Canning River to the Canadian border: U.S. Geological Survey Open-File Report 82-974, 67 p.

Reimnitz, Erk, Maurer, D.K., 1978, Storm surges in the Alaskan Beaufort Sea: U.S. Geological Survey Open-File Report 78-593, 26 p.

Reimnitz, Erk, Graves, S.M. and Barnes, P.W., 1985, Beaufort Sea coast erosion, shoreline evolution and sediment flux: U.S. Geological Survey Open-File Report 85-380, 70 p.

Reimnitz, Erk and Maurer, D.K., 1979, Eolian sand deflation; a cause for gravel barrier islands in Arctic Alaska?: Geology, v. 7, no. 10, p. 507-510.

Reiser, H.N., Brosgé, W.P., Dutro, J.T., Jr., and Detterman, R.L., 1974, Preliminary geologic map of the Demarcation Point quadrangle, Alaska: U.S. Geological Survey Miscellaneous Field Studies Map MF610 , scale 1:200,000.

Reiser, H.N., Brosgé, W.P., Dutro, J.T., Jr., and Detterman, R.L., 1980, Geologic map of the Demarcation Point quadrangle, Alaska: U.S. Geological Survey Miscellaneous Investigations Series Map I-1133, scale $1: 250,000$.

Reiser, H.N., Brosgé, W.P., Dutro, J.T., Jr., and Detterman, R.L., 1971, Preliminary geologic map, Mt. Michelson quadrangle, Alaska: U.S. Geological Survey Open-File Report 71-237, scale 1:200,000.

Reiser, H.N., Brosgé, W.P., Detterman, R.L., and Dutro, J.T., Jr., 1978, Geologic map of the Demarcation Point quadrangle, Alaska: U.S. Geological Survey Open-File Report 78-526, scale 1:250,000.

Reiser, H.N., Dutro, J.T., Jr., Brosgé, W.P., Armstrong, A.K., and Detterman, R.L., 1970, Progess map, geology of the Sadlerochit and Shublik Mountains, Mt. Michelson C-1, C-2, C-3, and C-4 quadrangles, Alaska: U.S. Geological Survey Open-File Report 440, scale 1:63,360, 5 sheets.

Rex, R.W., 1964, Arctic beaches, Barrow, Alaska, in Miller, R.L., ed., Papers in marine geology (Shepard Commemorative volume): New York, Macmillan, p. 384-400.

Rex, R.W., and Taylor, E.J., 1953, Uplifted beach ridges and first generation lakes in the Barrow area, Alaska: unpublished final report to NONR Contract NONR 225(09), Palo Alto, Calif., Department of Geology, Stanford University. 
Rickert, D.A., and Tedrow, J.C.F., 1967, Pedologic investigations of some eolian deposits of northern Alaska: Soil Science, v. 104, p. 250-262.

Roach, S.M., 1993, Alaska Department of Fish and Game flooded gravel mine studies since 1986 and an arctic grayling experimental transplant into a small tundra drainage : a synthesis: Alaska Department of Fish and Game, Habitat and Restoration Division, Technical Report 93-6, 39 p.

Rodeick, C.A., 1975, The origin, distribution, and depositonal history of gravel deposits on the Beaufort Sea continental shelf, Alaska: San Jose, San Jose State University, Calif., M.Sc. thesis, 87 p.

Rodeick, C.A., 1979, The origin, distribution, and depositonal history of gravel deposits on the Beaufort Sea continental shelf, Alaska: U.S. Geological Survey Open-File Report 79-234, 87 p.

Rodrigues, Robert, 1992, Bird use of abandoned gravel pads in arctic Alaska: 1990 and 1991: LGL Alaska Research Associates, Inc., BP Exploration (Alaska) Inc., 57 p.

RZA, Inc., 1983 Point Lay offshore and upland borrow source studies, Point Lay, Alaska: North Slope Bourough (Alaska), $1 \mathrm{v}$. (various foliations).

Sable, E.G., 1965, Geology of the Romanzof Mountains, Brooks Range, northeastern Alaska: U.S. Geological Survey Open-File Report 65-141, 218 p.

Sable, E.G., 1977, Geology of the western Romanzof Mountains, Brooks Range, Alaska: U.S. Geological Survey Professional Paper 897, 84 p.

Schlegel, M.G. and Mahmood, Arshud, 1985, Arctic earth materials for offshore construction in Alaska: Civil engineering in the arctic offshore, Proceedings of the Conference Arctic '85, Bennett, F.L and Machemehl, J.L. eds., New York, American Society of Civil Engineers, p. 524-540.

Schrader, F.C., 1904, A reconnaissance in northern Alaska across the Rocky Mountains, along the Koyukuk, John, Anaktuvuk, and Colville Rivers and the arctic coast to Cape Lisburne in 1901: U.S. Geological Survey Professional Paper 20, 139 p.

Sellmann, P.V., and Brown, Jerry, 1973, Stratigraphy and diagenesis of perennially frozen sediments in the Barrow, Alaska region, in International Conference on Permafrost, North American Contribution, 2nd, Yakutsk, U.S.S.R.: National Academy of Sciences, p. 171-181.

Sellmann, P.V., and Brown, Jerry, 1965, Coring of frozen ground, Barrow, Alaska: Hanover, N.H., U.S. Army Cold Regions Research and Engineering Laboratory, CRREL Special Report 82, 8 p.

Sellmann, P.V., Carey, K.L., Keeler, Charles, and Hartwell, A.D., 1972, Terrain and coastal conditions on the Arctic Alaskan Coastal Plain: Hanover N.H., U.S. Army Cold Regions Research and Engineering Laboratory, CRREL Special Report 165, 74 p.

Sellmann, P.V., Carey, K.L., Keeler, C.M., and Hartwell, A.d., 1972, Terrain and coastal conditions on the arctic coastal plain: U.S. Army Cold Regions Research and Engineering Laboratory Report. No. SR. 165/1, 83 p. [Arctic environmental data package supplement 1]

Short, A.D., and Wiseman, W.J., Jr., 1973, Freezing effects on arctic beaches: Louisiana State University Coastal Studies Bulletin 7, Technical Report 128, p. 23-32.

Short, A.D., and Wiseman, W.J., Jr., 1974, Freezeup processes on arctic beaches: Arctic, v. 27, p. 215-224.

Short, A.D., and Wiseman, W.J., Jr., 1975, Coastal breakup in the Alaskan Arctic: Geological Society of America Bulletin, v. 86, no. 2, p. 199-202.

Short, A.D., and Wright, L.D., 1974, Lineaments and coastal geomorphic patterns in the Alaskan Arctic: Geological Society of America Bulletin, v. 85, p. 931-936.

Short, A.D., 1975, Offshore bars along the Alaskan Arctic Coast: Journal of Geology v. 83, no. 2, p. 209-221.

Simpson, J.K. and Jarrett, P.J., 1983, Explosive excavation of frozen soils: Proceedings Permafrost, 4th International Conference, Washington, DC, National Academy Press, p. 1160-1165.

Smith, P.S., and Mertie, J.B., Jr., 1930, Geology and mineral resources of northwestern Alaska: U.S. Geological Survey Bulletin $815,351, \mathrm{p}$.

Sohio Alaska Petroleum Company, 1981, Environmental effects of gravel island construction, Endeavor and Resolution Islands, Beaufort Sea, Alaska, Northern Technical Services, Sohio Alaska Petroleum Company, $62 \mathrm{p}$.

Toimil, L.J., and Dunton, K.H., 1983, Environmental effect of gravel island construction OCS-Y0191 (BF-37) Beechey Point, Block 480, Stefansson Sound, Alaska : supplemental study: Harding Lawson Associates, Exxon Company U.S.A., v. 56 leaves

Truett, J.C., and Kertell, Kenneth, 1990, Effects of habitat disturbance on arctic wildlife : a review and analysis: final report: LGL Alaska Research Associates, BP Exploration (Alaska) Inc., 61 p. 
U.S. Department of the Interior, Bureau of Land Management, 1969, TAPS Yukon haul road : material sites and special land use permits $1 \mathrm{v}$. (unpaged).

U.S. Department of the Interior, Bureau of Land Management, 1970, Status report, TAPS haul road: Yukon River to Prudhoe Bay, 29 leaves.

U.S. Department of the Interior, 1976, Alaska Natural Gas Transportation System, final environmental impact statement, Part II, Alaska: Washington, D.C., 2 v., 778 p.

U.S. Department of the Interior, 1976, Gravel removal studies in selected arctic and sub-arctic streams in Alaska : preliminary report, U.S. Department of Interior, Fish and Wildlife Service, Office of Biological Services, $127 \mathrm{p}$.

U.S. Department of the Interior, 1980, Gravel removal studies in arctic and subarctic floodplains in Alaska : U.S. Department of the Interior, Water Resources Analysis Project, Office of Biological Services, Technical Report, $403 \mathrm{p}$.

U.S. Department of the Interior, Mineral Management Service, 1983, Final environmental impact, proposed outer continental shelf arctic sand and gravel lease sale, $37 \mathrm{p}$.

U.S. Department of the Interior, 1988, Surface disturbance activities in Alaska: A guide to technical aspects of mitigation and reclamation: Alaska, BLM-Alaska Technical Bulletin, AK-BLM-PT-87-008-1610-933.

U.S. Fish and Wildlife Service, 1983, Proposed oil and gas exploration within the coastal plain of the Arctic National Wildlife Refuge, Alaska, final Environmental Impact Statement and preliminary final regulations: Washington, D.C., 147 p., with appendices.

U.S. Geological Survey, 1979, An environmental evaluation of potential petroleum development on the National Petroleum Reserve in Alaska: prepared by the U.S. Geological Survey, under Section 105(b) of the Naval Petroleum Reserve, Production Act of 1976, 238 p.

Vita, C.L., Rooney, J.W., Riddle, C.H., and Acomb, L.J., 1984, Dalton Highway characterization of foundation soils: Alaska Department of Transportation and Public Facilities Report AK-RD-85-28, 81 p.

Walker, D.A., Cate, D., Brown, Jerry, and Racine, E., 1987, Disturbance and recovery of arctic Alaskan tundra terrain: Hanover, N.H., U.S. Army Cold Regions Research and Engineering Laboratory, CRREL Report $87-11,63 \mathrm{p}$.

Walker, D.A., Walker, M.D., Everett, K.R., and Webber, P.J., 1985, Pingos of the Prudhoe Bay region, Alaska, USA: Arctic and Alpine Research, v. 17, no. 3, p. 321-336.

Walker, D.A., Webber, P.J., Binnian, E.F., Everett, K.R., Lederer, N.D., Nordsfrand, E.A., and Walker, M.D., 1987, Cumulative impacts of oil fields on northern Alaskan landscapes: Science, v. 238, p. 757-761.

Walker, H.J., 1973 Morphology of the North Slope, in Britton, M. E., ed., Alaskan arctic tundra: Washington, D.C., Arctic Institute of North America Technical Paper 25, p. 49-92.

Walker, H.J., 1975, Intermittent arctic streams and their influence on landforms: Catena, v. 2, p. 181-192.

Walker, J.H., 1994, Environmental impact of river dredging in arctic Alaska (1981-89): Arctic v. 47, no. 2, p. 176-183.

Walker, D.A., Cate, D., Brown, J., and Racine, C., 1987, Disturbance and recovery of arctic Alaska tundra terrain a review of recent investigations: U.S. Army Cold Regions Research and Engineering Laboratory Report $87-11,63 \mathrm{p}$.

Webber, P.J., 1984, Terrain sensitivity and recovery in Arctic regions, in International Conference on Permafrost, 4th, Fairbanks, Alaska, 1983, Final Proceedings: Washington, D.C., National Academy Press, p. 135136.

Wellman, J.H., Clarke, E.S. and Condo, A.C., 1977, Design and construction of synthetically insulated gravel pads in the Alaska arctic: Proceedings of the Second International Symposium on Cold Regions Engineering: College, Alaska p. 62-85.

Williams, J.R., 1970, A review of water resources of the Umiat area, northern Alaska: U.S. Geological Survey Circular 636, $8 \mathrm{p}$.

Williams, J.R., 1983, Engineering-geologic maps of northern Alaska, Meade River quadrangle: U.S. Geological Survey Open-File Report 83-294, 29 p., scale 1:250,000.

Williams, J.R., 1983, Engineering-geologic maps of northern Alaska, Wainwright quadrangle: U.S. Geological Survey Open-File Report 83-457, 28 p., scale 1:250,000.

Williams, J. R., and Carter, L.D., 1984, Engineering-geologic maps of northern Alaska: Barrow quadrangle: U.S. Geological Survey Open-File Report 84-124, 39 p., scale 1:250,000, 2 sheets. 
Williams, J.R., Carter, L.D., and Yeend, Warren, 1978, Coastal plain deposits of NPRA, in Johnson, K.M., ed., The United State Geological Survey in Alaska - Accomplishments during 1977: U.S. Geological Survey Circular 772-B, p. B20-B22.

Williams, J.R., Yeend, Warren, Carter, L.D., and Hamilton, T.D., 1977, Preliminary surficial deposits map of National Petroleum Reserve - Alaska: U.S. Geological Survey Open-File Report 77-868, scale 1:500,000, 2 sheets.

Williams, J.R. and Yeend, Warren, 1979, Deep thaw lakes of the inner Arctic Coastal Plain, Alaska, in Johnson, K.M. and Williams, J.R., eds., United States Geological Survey in Alaska-Accomplishments during 1978: U.S. Geological Survey Circular 804-B, p. 35-37.

Winters, J.F., 1990, A transplant of Arctic grayling to a flooded gravel mine site in the Kuparuk River oilfield: Alaska Department of Fish and Game, Habitat Division, Technical report no. 90-4, 26 p.

Wiseman, W.J., Jr., Coleman, J.M., Gregory, A., Hus, S.A., Short, A.D., Suhayda, J.N., Walters, C.D., Jr., and Wright, L.D., 1973, Alaskan arctic coastal processes and morphology: Baton Rouge, Louisiana State University Coastal Studies Institute, Technical Report 149, 171 p.

Woodward-Clyde Consultants, 1976, Gravel removal studies in selected Arctic and subarctic streams in Alaska, San Francisco, 134 p.

Woodward-Clyde Consultants, 1980, Gravel removal guidelines manual for Arctic and Subarctic floodplains: U.S. Fish and Wildlife Service FWS/OBS-80/09 169 p.

Woodward-Clyde Consultants, 1980, Gravel removal studies for Arctic and Subarctic floodplains: U.S. Fish and Wildlife Service FWS/OBS-80/80, 403 p.

Yeend, Warren, 1973, Preliminary geologic map of a prospective transportation route from Prudhoe Bay, Alaska to Canadian border, Part 2, Mt. Michelson quadrangle, Alaska: U.S. Geological Survey Miscellaneous Field Studies Map MF-494, scale 1:125,000.

Yeend, W.E., 1973, Preliminary geologic map of a prospective transportation route from Prudhoe Bay, Alaska to Canadian border, Beechey Point and Sagavanirktok quadrangles: U.S. Geological Survey Miscellaneous Field Map, MF-489, 1 sheet, scale 1:125,000.

Yeend, Warren, 1978, Surficial geology of the foothills and mountains of NPRA, in Johnson, K.M., ed., The United States Geological Survey in Alaska - Accomplishments during 1977: U.S. Geological Survey Circular 772-B, p. B19-B20.

Yeend, Warren, 1983, Engineering-geologic maps of northern Alaska, Lookout Ridge quadrangle: U.S. Geological Survey Open-File Report 83-279, scale 1:250,000, 2 sheets.

Yeend, Warren, 1984, Engineering-geologic maps of northern Alaska, Utukok River quadrangle: U.S. Geological Survey Open-File Report 84-682, scale 1:250,000, 2 sheets. 